\title{
Philosophy of Education in Culture "Saycico" in West Halmahera Regency
}

\author{
Bakar Djibat ${ }^{1}$ \\ \{akadjibat@gmail.com ${ }^{1}$ \} \\ Faculty of Education, Muhammadiyah Univercity of North Maluku, Indonesia ${ }^{1}$
}

\begin{abstract}
This study aims to reveal the development of education based on local wisdom in the "Saycico" culture in West Halmahera district, North Maluku province. Research This is a qualitative study using the intended descriptive approach to explore and clarify the "Saycico" culture in the district community West Halmahera, by describing a number of variables with respect to this problem. The phenomenon of this research is building wisdom-based education local "Saycico". This phenomenon is then implemented in life society so that it is always sustainable and continues to be carried out by every generation at the time to come. This study is not intended to test a specific hypothesis, but only describe the symptoms as mentioned above, namely a qualitative approach where researchers are not limited by certain measuring instruments. Research data were collected through observation techniques, in-depth interviews, and documentation techniques. This research data analyzed using continuous interactive qualitative analysis techniques. This research produce findings that, education and culture are related, namely with education can shape human beings who are cultured, and with culture, can guide humans to live according to the rules or norms that are used as guidelines in live life by exploring and applying a number of local wisdom thriving in communities including "Saycico".
\end{abstract}

Keywords: Education, multicultural, social solidarity, "Saycico" culture

\section{Introduction}

Local culture and values wisdom that have developed hereditary in society is a source at once so rich inspiration. It is the basic capital in education for formation of individual and nation character. To do this is required inventory, codification and revitalization sustainable by reenact and putting it in the current context. Such values according to Djibat [1] can be seen from the tradition of various tribes in Indonesia, such as gotong-royong culture, the discipline culture, the culture of punctuality, self-sacrifice, mutual respect, tolerance, hapolas, sopik, makayaklo, saycico, and so on. The dynamics of relationships between ethnicities, between cultures, between religions, leaves a trail of problems that deeply affected the integrity of the nation. Cultural identity is a phenomenon that often causes tension and conflict between resident and ethnic in Indonesia.

Understanding of unity feeling, mutual respect and appreciated (tolerance) and in the same boat feeling (empathy) in social life, national and state life have not been deeply ingrained. Azyumardi Azra [2] says that culture covers so vast aspect reflected in the behavior and work of the children nation, starts from specific works of art to familiar works such as the economic, educational and agricultural system of Indonesian people who are unique in their own way. The cultural treasures and uniqueness of each region need to be maintained and conserved. Culture 
should not be left to run, grow and develop without attention and guidance, much more should it be expected to have a role in education and growth and the development of the human society in which it resides. Governments and society have similar responsibilities in advancing culture.

The value of education in any local wisdom is usually associated with the environment to solve the issues and difficulties are faced by society. But the fact is that governments are now not only observing the centralized policies and shaping the national culture, but also giving little attention to local wisdom by enforcing uniformity and avoiding diversity. Regional autonomy in one aspect is able to be minded as an effort to increase back local wisdom that loss all the time from multicultural society of Indonesia. In fact, regional autonomy is likely to be a burden on the development of a harmonious multicultural society. It can be observed from the from decrease a tolerance of society from difference, that there is a narrow understanding of the meaning in "locality" packed into the local "son's" vocabulary, this is our village, it has your land, doesn't it? That result an emergence of a ruler or small Kings, and lessening rate of trusting each other in society's lives. These things become a booster and trigger that appearance many problems which the source comes from a plurality, such as people riot that often happened, terrorism, between village conflicts, tarkam, and problems caused by narrow understanding of ethnicity and identity cultural.

The rioting, conflicts and the rioting can develop continuously that requires us to start new efforts, by transforming the increment and multifaceted paradigms of community and national life. In this case, it is the strongest repelling against all forms of threats or views that could destabilize national life with an education that still holds firm to the outlook of Indonesia. A research also tried to give another perspective on the development of a harmonious public education in the local autonomy region by attempting to revive the spirit of multiculturalism among Indonesian, especially in the north Maluku province was an area of conflict.

\section{Literature Review}

According to language, says saycico comes from region language "Sahu" in west Halmahera district, which means "it is very delicious, it is very good taste, it is great, it is correct, it is elegant, or harmonious." The people of west Halmahera believe that if there is a cross between culture and education in one region it will result in intelligent children, respect and uphold cultural values and seek to preserve, and pass on to the next generation. According to Magdalena Leftew (a girl of jailolo/interview on August 2, 2019) says, in the saycico culture, the relationship between education and culture is inseparable, that is why Bhimji [3] saying at least key words, namely, education is acculturation (culture) institutionalization (transitory), transfer (inherited), imparting (giving, illustrating), and parting (directing). Umi, Rajab, Margana and Abdul [4] say that "saycico" culture emphasizes education and culture are very closely linked. According to Bigo [5], education is inseparably linked with culture. Without the education process it would not be possible for such a culture to thrive. Thus, Bleiker, Campbell, Hutchison, and Nicholson [6] suggests that the educational process may be called the transmission of culture. In an anthropological perspective, education is the transformation of the cultural social system from one generation to the next in a society. Explained that education is a process of cultivation. In other words, education and culture have unbreakable relationships. Morris [7] emphasizes that when it comes to education, culture participates in it, rather than in one area, and the system and methods of education are discussed. Chouliaraki [8] says there is no culture without education and neither is education always within the cultural sphere. 
According to Arman [9] the cultural values of West Halmahera of north Maluku province belong to the nation as a priceless potential for Indonesian building and advancement. Any, Lie [10] says that the people of west Halmahera are pluralistic in both cultural, religious and language communities that have the highest values as its local cinema. That's why Tuli Kuso (a prominent local producer of Sahu/interview on August 25, 2019) said that there are a number of proven traditional educational practices, such as the indigenous Balisoan, Tacici, Taraudu, and Worat-worat in preserving the environment by growing fruit behind each other's houses, more of the cultivated fruit plants composed of Langsa, Duku, Rambutan, and Cempedak, while in their gardens, They grow Durian more. Martinus Mess (the head of Worat-worat/interview of August 4, 2019) says over 80 percent of the families in west Halmahera especially "Sahu" must have the durian tree.

As for the central center/place of the first educational process for the prosperity of west Halmahera named "Sasadu". To this day, "Sasadu" is still well cared for in almost every village. But this did not mean that there were no schools, all the children went on to their formal education. The entire society in west Halmahera according to Nanuru [11] has arranged for what might be called a traditional education, including a well-meaning intelligence education. The people of west Halmahera remain to this day in existence keeping his local whiskey an integral part of daily life and the basis for solutions to the problems of its societies.

"Saycico" has a very deep philosophy for the people of west Halmahera because it contains strong social solidarity especially in education. Social solidarity is so important that Durkheim (12) speaks of him as a moral source for establishing a social order in society. Alcalde and Portos [13] proclaiming the origin of moral authority must be traced to something rather vague called "society." Durkheim developed two related philosophies to explain social realities. Both philosophies according to Rakopoulos [14] are collective consciousness or collective conscience and the collective picture of society. The collective consciousness according to Della Porta [15] is a normatiti consensus that includes beliefs about religion or other beliefs that support it. According to Cabot [16], collective consciousness varies from one society to another. Whereas the collective picture resulting from this study is symbols that have the same meaning for all members of society and allow them to feel band together. That is why the collective picture for Seymour [17] is part of the collective consciousness, an entity existing in the metaphysical society of west Halmahera and a more proscribed public opinion reality. According to AlThahab \& Abdelmonem [18] collective consciousness carries all the thoughts are Shared by members of society and serve a collective purpose and purpose. The collective consciousness referred to in this study is to make everyone in the western halmahera family into a human servant. That is why before it is revealed the values embodied in the culture "saycico", each family still lives on its own asa trigger grows a sense of narrow egotism.

"Saycico's cultural solidarity is based on mutual interdependence. That is co-dependency according to Shaleha and Purbani [19] increasing as a result of increasing specialization in the division of jobs, it is also a catalyst and a catalyst for increasing inequality in society. The rise of differences at the individual level, as Mohanty [20], is concerned by some members of society, as it can cause collective consciousness, which in turn would be a danger to social order. Ismail Guret (a jailolo/interview public on August 24, 2019) points out that the power of this solidarity is marked by the importance of a (Restive) law over a repressive one, in which in "saycico culture" the purpose of the two types of law is very different. According to Agustin \& Orgensen [21], repressive laws express intense collective feelings of anger, restive laws that serve to maintain or protect interdependent patterns between various specialized individuals or groups and families in the community. Relate to this problem, Husen Abd. Fattah (a public denser of jailolo/interview on August 5, 2019) says there are two things that should get attention. 
First is the rise of phenomenon according to the ethical standards among students. Second, there are no character education models in schools that match the religious and cultural values that can shape the character of students. Thus, it needs to be sought out and formulated effective character education models to be implemented in schools in west Halmahera.

Based on the foregoing, the study also seeks to promote a core education that cannot escape the backbreaking culture of west Halmahera society. Every tribe in the west Halmahera that bhinneka basically has its own culture, has its own noble cultural values, and has local wisdom (local knowledge, or local wisdom) itself. According to Hikmansyah [22] this is what has brought about the deliberative education that is "every society seeks to convey fundamental ideas concerning the nature of the world, knowledge and values."

In view of our education practices, we are too western-oriented to forget the values of excellence in Indonesia. It is expressed by Sajir \& Miriyam [23] that any of us have been blinded to the western educational system so long that it is blind to the old native superiority buried in the earth of Indonesian culture. The condition was enhanced by the Indonesian university of education (UPI) by the derogatory program etnopedagogy. The etnopedagogy referred to in this study is a local wisdom based educational practice. Local wisdom is the process by which knowledge is produced, stored, applied, and passed on (Alwasilah,). Therefore, it needs to be destroyed and formulated with local culture-based character education models for people of this culturally diverse west Halmahera society.

As noted earlier, "saycico" comes from "Sahu" language, one of the oldest tribes in the west Halmahera district that means: it is very delicious, it is very good taste, it is great, it is correct, it is elegant, or harmonious." That's why the concept of social solidarity that is the central concept of Emile Durkheim develops sociological theory. Durkheim [13] stated that social solidarity is a state of relationship between individuals and/or groups based on a Shared moral sense and trust strengthened by mutual emotional experience. Ciambele. Jose, Fernada, and Victor [24] says solidarity emphasizes on the state of relationships between individuals and groups and underpinning mutual attachment in life with the support of the moral values and beliefs that live in society. That's why Kelliher [25] says the real manifestation of a common relationship will give rise to emotional experiences, thus strengthening the relationship between them.

Social solidarity according to Arbon, Cusack, Gebbie, Steenkamp, and Anikeeva [26], it may also be interpreted as an expression of collective or individual concern that demonstrates a state of relationship between indvids and or groups based on the same collective moral equality, and a belief embraced and strengthened by emotional experience. Saying social solidarity can be based on a variety of similar racial, tribal and emotional similarities so that they have a strong desire to improve things and areas or neighborhoods so that they can improve things a little by helping each other to a little more in the way of development. According to Brian [27] social solidarity is also influenced by social interaction that persists because of cultural ties, which are basically caused by the appearance of community sentiment.

Main feature of (plural society) according to Martin, Pritchard, Sorensen [28] was a physically coexisting person, but because of their social differences were fragmented and did not join a political unit. Classic example of Indonesian people in colonial times. That is why the Dutch Indies society was then divided, not only between ruling and governed groups separated by different Races, but it functions as part of economic units, between Chinese, Arab, and Indian farmers. 


\section{Method}

The study is a qualitative study with a string of phenomena intended to unearth and analyze the philosophy of education in "Saycico" culture in the west Halmahera district, while it is intended to preserve local wisdom and build social solidarity with people in a way that describes a number of variables. The time and place of this study lasted 10 (ten) months, from June 2019 to March 2020. The study picks up location in 4 (four) districts in the west Halmahera province of north Maluku, that is: Jailolo, Sahu, east Sahu, and Ibu district, which still maintain and uphold the local culture and wisdom of "saycico." It is hoped that each of the four subsets can provide a detailed and holistic overview of the data needed for the research.

Research subject are based on research performed and needed data. In qualitative research with a phenomenon approach, the selection of a research subject is very important, that of those who know and or experience the case. Jailolo district, the choice of the subject based on the Suggestions and recommendations of the west Halmahera district's branch of education and culture, and because it is recognized asa substandard that to this day stands firm on saycico's local wisdom with a philosophy inherent in it. Sahu district, the choice of this subject aside from the Suggestions and recommendations of the west Halmahera district's branch of education and culture, as well as because it is a sub district populated by the indigenous west Halmahera tribe, and is still holding the local culture and wisdom values. East Sahu district, the choice of this subject is not only based on the Suggestions and recommendation of the west Halmahera district's branch of education and culture, but also because it represents an extension of sahu district in which saycico culture is born, its population is homogeneous, while some are immigrants, and it is dominated by Sahu and Tobaru ethnicity. Ibu district, the choice of this subject is made aside from the Suggestions and recommendations from head of west Halmahera district's branch of education and culture, as well as because it is one of the oldest districts in west Halmahera, and is already composed of several. To this day, the largest sub district ibu district carries out the "saycico" culture, it is inhabitants are also heterogeneous, but the vernacular is dominated by Gamkonora, Waiyoli and Tobaru language.

This research incorporation data is done by observation, interviews, and documentaries to uncover and analyze the cultural phenomenon of saycico in the education of west Halmahera district as an effort to preserve local wisdom and build social solidarity, by way of which a number of variables on the matter, and other factors that contribute to the preservation and cultural heritage of the community. With the technique it will acquire main data and additional data. Words and actions in the implementation of saycico culture" with statements from the tribal elders, as well as the public figures of the four-sub district, which is the main data in the study.

\section{Results and Discussion}

\subsection{The results of the study of the multicultural reality of West Halmahera}

West Halmahera district is one of the districts in North Maluku Province. The regency is an actual region is a master district when North Maluku is produced from Maluku province in 
1999. The district is inhabited by a very compound community, this is seen from its citizens derived from various tribes and regions in Indonesia, from North Maluku consisting of Ternate, Makian, Tobaru, Jailolo, Sahu, Tobelo, Waiyoli, Gamkonora and other. While from outside Maluku North, West Halmahera community comes from Bugis, Java, Ambon, Minang, Sangir, Manado, Buton, Batak, and China and other. As for religion, all religions in Indonesia are in West Halmahera, but who dominate is Protestant and Islam. Many local languages used in West Halmahera are; Languages of Ternate, Sahu, Gamkonora, Tobaru, Sangir, Waiyoli, Tobelo, and Language Makian. But in general, the introduction of the days is the Indonesian Dialek Malaku North or better known as the "Malay Ternate" language. Thus, understanding and awareness of the culture of "Saycico" that is thick to multiculturalism has actually appeared even before this district is formed through the pemekaran of North Maluku district and used by the founders of the nation to design the culture of the Indonesian nation we know "Bhinnekaka single IKA" which can show that Indonesia is in the country of multicultural states composed by many tribes. This study found, managing many tribes in West Halmahera districts in one flatform unlimited is not easy, especially when not all tribes in this district have the same historical experience. Naturally, if vertical and horizontal conflicts are still common, there may even be latent, and this is also hinted that plurality in Indonesia and West Halmahera, especially not in the multicultural level. The question is, this is solely because the primodial sentiment can not be abolished or there is a management error so that the primodial sentiment is very easy to fall and turn into conflict.? The important thing that has been realized together who often trigger conflicts in West Halmahera and Indonesia in general is the application of government policies through development slogans. Sometimes development programs based on target achievements do not really refine to the comprehensive study of community readiness and the effects of the program. Various conflicts that appear in the form of conflicts of tribal, religious, and interfaith religion (SARA) are suspected of having a root problem with the application of development policies impact on the formation of chronic and accumulative socioeconomic gaps. In viewing the phenomenon of the Hummahera Western community of the developing since the defending district of 1999 to date, it can be said that to prevent the occurrence of conflicts as to be reached, the government successfully implemented Sara (Tribe, Religion, Religious and Intergial) management. The government managed to form the religious order between religion in West Halmahera. The religious order is increasingly adaptive to integration supported by the role of religious institutions set through containers such as MUI (Ulama Indonesia Assembly), GMIH (Church of Ejiti Muhila Halmahera), Parishada Hindu Indonesia and Walubi.

West Halmahera community has its own social system and cultural system that distinguishes with other communities, including the culture of "Saycico" which is the focus of this research. They have a number of traditions or habits that are still implemented in everyday life and are also passed on to generation to date. Especially the "Saycico" culture is seen by the community is still functional and in accordance with the environmental demands of the public residence, which is still maintained and remains up to date. The tradition is always implemented and accompanies what activities in this district and are seen by the functionality by the community, so every time the citizens of the community to take place any of the events, this tradition remains held. The tradition that has been passed by the hereditary is still able to survive, although the community has been widely paid by various progress and development of the age. That is, changes in the time and era of globalization does not damage the existing tradition, despite various changes.

Portrait of Harmony Pompatu Kompatuk Akediri Design This research has successfully found, culture "Saycico" that is thick to multiculturalism and local aesthetics are understood as an effort to find local values, local wisdom, or like Azumyardi Azra views of the local Genius 
contained in the cultural region, such as history, language, the system of raising, live view, customary prauata, customs, literature, arts, and others. This effort appears none other than the form of concern will be broken the generation of a culture of a culture, not from the seneum of being renewed. The study also found, the West Halmahera community is a multicultural society characterized by tribal, religious, racial and class differences. History shows, each ethnic and tribe has its own local wisdom. Moreover, each has the familiarity and hospitality with its own environment. The local wisdom certainly does not appear by itself, but a long processing so that it is finally proven to be good for the good of the community that is multicultural.

The results of this study show everyone in West Halmahera districts that are internally always bound by norms, values, and traditions that naturally want a decent life and togetherness in realizing the safe, tentram, jun, and harmonious atmosphere. But still we often see all the people are able to create harmony and harmony, but otherwise whenever tend to lead to conflicts, riots, and mob beans. The study also found the bustle of social issues of social conflict caused by the multicultural conditions, there is one community community that has a social system of cultural life that reflects religious ability, belonging to the family of the family of Akederi, Jailolo District. This village community is inhabited by various ethnicisms and religions. All religions in Indonesia and almost all ethnicities are in this village, which according to Udin Lessy (the student of the Family of Agelediri village derived from Ambon / interview dated November 8, 2019) has many local wisdom values capable of creating public harmony. This village there has been a National Army Headquarters of Indonesia (TNI) of the Dan Banau Gun. Kasdi (one of the members of the TNI / interview 15 October 2019), which was given additional tasks by the priest at the Mosque of Komi, saying that the life of the family of the family of defaults in the field of religion is very loaded with humanitarian values. For them, there is an important thing to be maintained is togetherness and mutual trust, and this is the implied meaning of the "Saycico" culture.

Keeping the values of togetherness in conjunction with the life of society, the nation and the country are very thick in every community in this village. People are more primarily to live side by side without seeing their different social, religious and trusty-based backgrounds. For those differences are a gift and potential that can be synergized in life. The wholeness of harmonious life in peace to date is still maintained. It can be seen when there are families who are Christians do the huanja, then who helps cook and prepare food is the religion of Islam. Likewise the development of mosques or churches, the community helped each other for its financing, even Kasdi (interview on June 16, 2019) said when the Medidate of the Akederi Village was built, precisely the Chairman of the First Development Committee was the father of Julianis Maraw (the Christian Ableiri). The reality of social life of the community of the islandir village as it is said above, according to Imanuel money (the student of the family of the family of Akederi / interview 20 June 2019) becomes a considered unique and need to be preserved. The consistency in social society culture is the community in religious and trust diversity of a phenomenon that can be a model how to manage social harmony in multicultural society. The question is how to move the harmonious life pattern of the healthy village of Akederi to other areas in Indonesia? This is where the teacher's position is in the formation of the character of students through local wisdom.

Building a cultural-based harmonic community "Saycico" The results showed that local wisdom position in building the harmonious community life in West Halmahera district, it is good that we reselled what the local meaning of the wisdom. In the Indonesian Dictionary of Indonesia, Local means local, while Wisdom (wisdom) is the same as the wisdom. In general, the local Wisdom (canalist) can be understood as local wisdom, local wisdom, well-worth, embedded and followed by members of the community. According to Bernard Mess (the 
community of the Akelamo Village) interview of October 18, 2019), local wisdom or often called Local Wisdom for West Halmahera society, is used to be understood as human efforts by using his mind (cognition) to act and behave to something, object, or events that occur in certain rooms. The above understanding, is prepared etymologically, where the Wisdom is understood as a person's ability in using his minds in acting or acting as a result of assessment of something, object, or events that occur.

Gerson Leftew (Sahu community leader / interview on 26 July 2019) said, wisdom in West Halmahera is defined as wisdom / wisdom. Local wisdom "saycico" is an explicit knowledge that emerges from a long period that evolved together with the community and its environment in a local system that has been experienced together. The evolutionary process that is so long and inherent in society can make "saycico" a potential source of energy from the collective knowledge

Furthermore, Farida Domili (interviewed on July 24, 2019) said that in West Halmahera, a harmonious society, if understood at a glance, is a form of social life that emphasizes a democratic spirit and upholds human rights values. According to the results of this study, a harmonious society in West Halmahera, residents work together to build social ties, productive networks and non-governmental human solidarity to achieve the common good. Several indicators that can be used as a measure in realizing the achievement of a harmonious society in West Halmahera according to Abdurrahman Guret (Acango village community leader / interview on 23 July 2019), namely: 1) preservation of the existence of religion or teachings in society; 2) maintained and guaranteed security, order and safety; 3) to establish freedom of thought that is clear and healthy; 4) the establishment of a calm and serene family existence with full tolerance and consideration; 5) developing regional conditions that are democratic, polite, civilized and have high morals; and 6) the development of high professionalism of village officials to create good governance in the village, clean with authority and responsibility.

The results of this study indicate that in a multicultural society in West Halmahera, a diagonal relationship paradigm or reciprocal understanding is needed, to overcome the negative excesses of a problem of national disintegration. Therefore, multiculturalism in West Halmahera is not just a recognition of being different, but rather a symmetrical differentiation (symetrical differentiated citizenship) by recognizing the plurality of identities in society. This should be encouraged by local governments through policies in order to eliminate the emergence of narrow loyalties based on religion or ethnic ties. In addition, through this plurality of identities, the struggle for the interests of the local community is no longer trapped in low, sectarian primordial issues that can threaten local harmony itself. This research also found that the implementation of Regional Autonomy also necessitates providing political space and aspirations for the community to participate widely. The principle of acceptance and respect for the diversity of values is a proliferation of democratic principles that not only encourage participation from and empowerment for all groups of society.

James Wonggo (Tedeng village community leader / interview on December 13, 2019) said that the plurality and diversity of society and culture in West Halmahera is both a reality and a necessity, the original values of the West Halmahera community are values which are embedded in the multicultural concept, values such as Religious tolerance, social aggregation, cultural and ethnic pluralism, are the reasons why the people of West Halmahera chose the "Saycico culture which is more towards equality and harmony, and tolerance than other cultures with religious nuances. This necessity must be acknowledged honestly, accepted gracefully, managed carefully, and guarded with gratitude; It should not be rejected, ignored, ignored, and denied just because the plurality and diversity have caused negative excesses, including the clash of society and culture in various places in West Halmahera. This image of society makes us aware 
that an understanding of multiculturalism is a necessity for humans to face global challenges in the future. Thus, multicultural education in West Halmahera has two major responsibilities, namely preparing the younger generation to be ready to face the flow of outside cultures in the era of globalization and to unite a society consisting of various ethnicities and cultures. If these two major responsibilities can be achieved, then the possibility of community friction and the emergence of conflict can be eliminated. On the other hand, excessive local primordialism, religious fanaticism that is too strong or regional exclusivism that often appears along with the birth of the era of regional autonomy can be avoided.

\subsection{Character Education Based on Local Wisdom of West Halmahera}

Local wisdom that is properly excavated, polished, packaged and preserved can serve as an alternative way of life for the people of West Halmahera today and can be used to filter new / foreign values so as not to conflict with people's personalities and maintain harmonious human relations with the Creator, nature. Around, and each other. In this case, the values of local wisdom, as illustrated by the Akediri village community, can be used as a content in building student character to be important, especially in the goal of building citizens who have an awareness of multicultural community life.

Regarding the goal of building a harmonious society based on local wisdom, Samsuddin Leba (Sahu community leader / interview on November 2, 2019) proposed character education through local wisdom in West Halmahera to be introduced by teachers to students from an early age. All schools / madrasah students have racial and religious diversity, which can become a community laboratory for the application of character education. The interaction process that involves all parties in local wisdom is the same as studying the characteristics of the material being studied so that students can directly explore the character of these local events. Local wisdom has a very important meaning for students, because they will understand the struggle of their ancestors in various community activities, learn about the values of hard work, perseverance, and never give up which are characteristic of the people of West Halmahera and Indonesia in general, but needs to be emulated in the era of globalization which is full of changes.

Susanti Lolori (a female character from Ibu sub-district / interview, 16 November 2019) explained that education based on local wisdom in West Halmahera has been education that teaches students to always be close to the concrete situations they face everyday. This local wisdom-based education model is an example of education that has high relevance for life development skills, based on the empowerment of skills and local potential in each region. Local wisdom-based education can be used as a medium to preserve the potential of each region in West Halmahera. Regional potential is a specific potential resource owned by a particular region. Therefore, students who come to school cannot be likened to an empty glass, which can be filled easily, but they have brought the cultural values of their respective families and communities. Education based on local wisdom will certainly be successful if teachers understand the insights of local wisdom itself. A wise teacher must be able to insert local wisdom values into the learning process. However, it should also be understood that character education based on local wisdom is not necessarily suitable for the people of West Halmahera which are very heterogeneous. 


\section{Conclusion}

The educational philosophy contained in Saycico culture in West Halmahera district shows that social diversity is an inevitable condition (not an irrational social pathology). This means that building a spirit of multiculturalism means building equality in diversity that leads to the harmonization of life as emphasized in Saycico culture where the political process and actualization of the citizenship process is a process of political expression of recognition, not just a politics of redestribution. Given the importance of understanding multiculturalism in the development of West Halmahera, concrete efforts are needed to make it happen. We need to spread understanding and educate people on the importance of Saycico culture which is very thick with multiculturalism for human life. In other words, we need multiculturalism education that can deliver West Halmahera to achieve justice, prosperity and community welfare.

The people of West Halmahera deserve to return to their identities through re-meaning and reconstruction of the noble values of saycico's culture and local wisdom. Efforts to build a harmonious society in West Halmahera, what needs to be done is to explore the substantive meaning of saycico local wisdom, for example openness is developed and contextualized into honesty, and uniformity is replaced by diversity. At the same time, the results of this reconstruction need to be grounded and disseminated throughout society so that it becomes a solid identity of West Halmahera, not just a particular ethnic or community identity. In this case, the role and responsibility of teachers are needed to transfer the values of local wisdom through an offering of education-based character education.

\section{References}

[1] Djibat, B. (2018). Mengungkap Nilai-nilai Pendidikan Dalam Tradisi "Sopik" di Pulau Makian provinsi Maluku Utara. Ternate: Universitas Muhammadiyah Maluku Utara.

[2] Azra, Azyumardi, (2003). "From Civic Education to Multicultural Education: With Reference to the Indonesian Experience," Paper presented at Workshop" Multicultural Education in Southeast Asian Nations : Sharing Experience, Univensity of Indonesia, Depok 17-19 June 2003.

[3] Bhimji, F. (2016). Collaborations and performative agency in refugee theater in Germany. Journal of Immigrant \& Refugee Studies, 14(1), 83-103.

[4] Barjiyah Umi, Rajab Umar Hi, Margana Sri, Wahid Abdul, (2017). Integrasi Sejarah dan Nilai Budaya Rumah Adat Sasadu di Jailolo-Sahu dalam Historiografi dan Kebudayaan Nasional (Laporan Akhir Penelitian Kerjasama Antar Perguruan Tinggi), Ternate: LPPM Universitas Khairun.

[5] Bigo, D. (2014). The (in) securitization practices of the three universes of EU border control: Military/navy - Border guards/police—Database analysts. Security Dialogue, 45(3), 209-225.

[6] Bleiker, R., Campbell, D., Hutchison, E., \& Nicholson, X. (2013). The visual dehumanisation of refugees. Australian Journal of Political Science, 48(4), 398-416.

[7] Boudreau Morris, K. (2017). Decolonizing solidarity: Cultivating relationships of discomfort. Settler Colonial Studies, 7(4), 456-473.

[8] Chouliaraki, L. (2013). The ironic spectator: Solidarity in the age of post-humanitarianism. Cambridge, UK: Polity Press.

[9] Arman Ayu, (2015). Festival Teluk Jailolo: Celebratingthe People, Culture and Nature of West Halmahera, Jailolo: Nala Publishing House.

[10] Any, Nanda Ravela Lie, (2017). Peran Lembaga Adat dalam Pelestarian Kearifan Lokal (Orom sasadu/Makan Adat) Suku Sahu di Desa Balisoan Kecamatan Sahu Kabupaten Halmahera Barat(Skripsi), Salatiga: Program Susi Sosiologi, Fakultas Ilmu Sosial dan Ilmu Komunikasi, Universitas Kristen Satya Wacana. 
[11] Ricardo Freedom Nanuru. (2019) Orom Sasadu: Hakikat dan Maknanya Bagi Masyarakat Suku Sahu di Halmahera Barat, Maluku Utara. Ambon: Fakultas Teologi Universitas Kristen Indonesia Maluku

[12] Emile Durkheim (1990). Pendidikan Moral, Suatu Studi Teori dan Aplikasi Sosiologi Pendidikan. Jakarta: Erlangga.

[13] Alcalde, J., \& Portos, M. (2018). Refugee solidarity in a multilevel political opportunity structure: The case of Spain. In D. Della Porta (Ed.), Solidarity mobilizations in the "refugee crisis"

[14] Rakopoulos, T. (2016). Solidarity: The egalitarian tensions of a bridge-concept. Social4Anthropology.

[15] Della Porta, D. (2018). Contentious moves: Mobilising for refugees' rights. In D. Della Porta (Ed.), Solidarity mobilizations in the "refugee crisis": Contentious moves (pp. 1-38). Cham, Switzerland: Palgrave Macmillan.

[16] Cabot, H. (2016). "Contagious" solidarity: Reconfiguring care and citizenship in Greece's social clinics. Social Anthropology.

[17] Seymour, T. (2016). Exodus. British Journal of Photography, University Press. (7851), 29-31.

[18] Ali Aumran Al-Thahab, Mohamed Gamal Abdelmonem. (2019). Changing Socio-Spatial Systems of Urban Living in Twentieth Century Iraq. Archnet-IJAR. ISSN: 2631-6862.

[19] Mustikaning Ayu Shaleha and Widyastuti Purbani. (2019). Using Indonesian Local Wisdom As Language Teaching Material to Build Students' Character in Globalization Era. IsoLEC, International Seminar on Language, Education, and Culture. Volume 2019

[20] Mohanty, C. T. (2002). "Under Western eyes" revisited: Feminist solidarity through anticapitalist struggles.

[21] Agustín, Ó., \& Jørgensen, M. (2016). Solidarity without borders: Gramscian perspectives on migration and civil society alliances. London, UK: Pluto Press.

[22] Hikmansyah, (2016). Bentuk dan Fungsi Rumah Sasadu Sebagai Pusat Kegiatan Masyarakat Sahu Kabupaten Halmahera Barat Maluku Utara, Prosiding Seminar Nasional Sustainable Architecture and Urbanism, Semarang: Universitas Diponegoro. p. 68-83.

[23] Zakaria Sajir \& Miriyam. (2019). Solidarity, Social Media, and the "Refugee Crisis": Engagement Beyond Affect. University of Leicester, University of Westminster, UK. International Journal of Communication 13 (2019), 550-577

[24] Ciambele J, Jose R, Fernada A, Victor P. (2015). Solidarity and Community Resilience in a Disaster Situation: An Understanding of Communitarian Ergonomics. Melbourne [AUS].: http://www.iea.cc/congress/2015/1347.pdf

[25] Kelliher, (2016). Constructing a Culture of Solidarity: London and the British Coalfields in the Long 1970s. Antipode 49 (1)

[26] Arbon P, Cusack L, Gebbie K, Steenkamp M, Anikeeva O. (2013). How do we measure and build resilience against disaster in communities and household?. Adelaide (AU): Torrens Resilience Institute

[27] Hayden Brian, (2014). Competitive Feasting before Cultivation?A Comment on Asouti and Fuller, Current Anthropology, Vol. 55, Number 2. p.230-231.

[28] Creswell, W. John. (2013). Research design; pendekatan kualitatif, kuantitatif dan mixed. Edisi ketiga. Yogyakarta: Pustaka Pelajar 